\title{
Cardiac interventional procedure in the United Kingdom during 1990
}

Table 1 Percutaneous transluminal coronary angioplasty in 1990

\begin{tabular}{ll}
\hline Country & $\begin{array}{l}\text { No/million } \\
\text { population }\end{array}$ \\
\hline United States & 1072 \\
Belgium & 569 \\
Holland & 545 \\
West Germany & 543 \\
Canada & 453 \\
France & 400 \\
Switzerland & 354 \\
Austria & 229 \\
Japan & 200 \\
United & \\
$\quad$ Kingdom & 148 \\
Italy & 79 \\
Spain & 60 \\
\hline Source: Intervention & Ltd, \\
1 Redman Court, Bell \\
Street, Princes Risborough, \\
Buckinghamshire.
\end{tabular}

Table 2 Percutaneous transluminal coronary angioplasty in the United Kingdom in 1990: Number of procedures per annum in 51 cardiac units

\begin{tabular}{cc}
\hline Procedures & Units \\
\hline $0-50$ & 5 \\
$51-100$ & 11 \\
$101-150$ & 11 \\
$151-200$ & 5 \\
$201-250$ & 5 \\
$251-300$ & 7 \\
$301-350$ & 6 \\
$351-400$ & 0 \\
$401-450$ & 1 \\
\hline
\end{tabular}

British

Cardiovascular Intervention Society

P J B Hubner

Correspondence to Dr P J B Hubner, Department of Cardiology, Groby Road Hospital, Groby Road, Leicester LE3 9AE.

Accepted for publication 4 April 1992

\section{Peter J B Hubner on behalf of the British Cardiovascular Intervention Society}

The British Cardiovascular Intervention Society asked cardiac units that performed adult and paediatric interventional procedures for information on the procedures that had been performed between 1 January and 31 December 1990. This was the third year of this form of audit. Records were obtained from 51 adult cardiology units including nine private hospitals. There were two fewer units than in the 1989 survey because two units had combined (National Heart Hospital and Brompton Hospital) and one unit, the Victoria Infirmary Glasgow, was unable to provide any information on its interventional procedures. There were 21 paediatric cardiology units, defined in this report as any hospital performing paediatric cardiological interventional procedures. In this report there were five new units which were not included in the 1989 report. One private unit from the 1989 survey did not perform paediatric procedures in 1990 (see appendix A). The results of this survey should be read in conjunction with those of 1988 and $1989 .^{12}$

\section{Percutaneous transluminal coronary angioplasty \\ NUMBER OF PROCEDURES}

There were 8459 procedures recorded (148 per million population). The rate of increase from 1989 was $18 \%$ compared with a $42 \%$ increase from 1988 to 1989 . Table 1 compares the United Kingdom figures with those of other countries. In $199013 \cdot 2 \%$ of total percutaneous transluminal coronary angioplasty procedures were performed in private hospitals. The number of cardiac units performing 150 or more procedures a year increased from 23 to 24 (table 2).

Table 3 Percutaneous transluminal coronary angioplasty in the United Kingdom during 1990: data from 51 cardiac units and 8459 procedures

\begin{tabular}{lcc}
\hline Data & Mean (\%) & Range (\%) \\
\hline Mortality (7840) & 0.71 & $0-3.2$ \\
Emergency coronary artery & 2.14 & $0-11 \cdot 1$ \\
bypass grafting (7818) & 1.91 & $0-8.5$ \\
Myocardial infarction (6698) & 86 & $59-100$ \\
Success (7229) & &
\end{tabular}

Numbers in parentheses are the total number of procedures for which information was available.
RESULTS OF PERCUTANEOUS TRANSLUMINAL CORONARY ANGIOPLASTY

Some units were unable to provide full data in response to all the questions that were asked. The results in this survey and its tables show the number of cardiac units and the number of procedures from which the information was derived.

The overall results of coronary angioplasty and the results from single vessel dilatation and from multivessel dilatation in 1990 are shown in tables 3-5. The overall results for 1990 were similar to those of 1989 . Mortality for single vessel dilatation progressively increased from $0.37 \%$ in 1988 , to $0.42 \%$ in 1989 , and to $0.62 \%$ in 1990 . The emergency coronary artery bypass graft rate during these years was $2 \cdot 3,1 \cdot 6$, and $2.0 \%$ respectively. Eighty three percent of percutaneous transluminal coronary angioplasty procedures were for single vessel dilatation-that is, for true single vessel disease or where one vessel was dilated in the presence of multivessel disease. For multivessel dilatation the average number of vessels dilated was $2 \cdot 1$. The mortality between 1988 and 1990 fell progressively from $1.6 \%$ in 1988 , to $1.3 \%$ in 1989 , and to $1 \cdot 1 \%$ in 1990 . The emergency

Table 4 Percutaneous transluminal coronary angioplasty in the United Kingdom in 1990: single vessel dilatation (data from 45 cardiac units)

\begin{tabular}{|c|c|c|}
\hline Data & Mean (\%) & Range (\%) \\
\hline $\begin{array}{l}\% \text { of total percutaneous transluminal } \\
\text { coronary angioplasty }(6012) \\
\text { Mortality (5673) }\end{array}$ & $\stackrel{1}{83}$ & $\begin{array}{c}54-100 \\
0-2.9\end{array}$ \\
\hline $\begin{array}{l}\text { Emergency coronary artery } \\
\text { bypass grafting }(5673) \\
\text { Myocardial infarction (5189) } \\
\text { Success }(5460)\end{array}$ & $\begin{array}{l}2 \cdot 0 \\
1 \cdot 6 \\
86\end{array}$ & $\begin{array}{c}0-11 \\
0-4 \cdot 2 \\
68-100\end{array}$ \\
\hline
\end{tabular}

Numbers in parentheses are the total number of procedures for which information was available.

Table 5 Percutaneous transluminal coronary angioplasty in the United Kingdom in 1990: multivessel dilatation (data from 43 cardiac units)

\begin{tabular}{|c|c|c|}
\hline Data & Mean (\%) & Range (\%) \\
\hline \multicolumn{3}{|c|}{$\%$ of total percutaneous transluminal } \\
\hline Mortality (1376) & $1 \cdot 1$ & $0-20$ \\
\hline \multicolumn{3}{|l|}{ Emergency coronary artery } \\
\hline bypass grafting (1258) & $2 \cdot 6$ & $0-18$ \\
\hline Myocardial infarction (1004) & $2 \cdot 9$ & $0-18$ \\
\hline Success $(1179)$ & 87 & $40-100$ \\
\hline
\end{tabular}

Numbers in parentheses are the total number of procedures for which information was available. 
Table 6 Percutaneous transluminal coronary angioplasty in the United Kingdom in 1990: clinical indications

\begin{tabular}{|c|c|c|c|c|c|c|}
\hline & $\begin{array}{l}\text { Unstable } \\
\text { angina }\end{array}$ & $\begin{array}{l}\text { Post } \\
\text { thrombolysis }\end{array}$ & $\begin{array}{l}\text { Acute } \\
\text { myocardial } \\
\text { infarction }\end{array}$ & $\begin{array}{l}\text { Repeat } \\
\text { Percutaneous } \\
\text { transluminal } \\
\text { coronary } \\
\text { angioplasty }\end{array}$ & $\begin{array}{l}\text { Chronic } \\
\text { occlusion }\end{array}$ & $\begin{array}{l}\text { Previous } \\
\text { Coronary } \\
\text { artery } \\
\text { bypass } \\
\text { grafting }\end{array}$ \\
\hline $\begin{array}{l}\text { Cardiac units } \\
\text { Total procedures } \\
\text { Mortality }(\%) \\
\text { Emergency coronary artery bypass }\end{array}$ & $\begin{array}{c}34 \\
1349 \\
0 \cdot 8\end{array}$ & $\begin{array}{c}26 \\
356 \\
2 \cdot 2\end{array}$ & $\begin{array}{r}26 \\
146 \\
5 \cdot 9\end{array}$ & $\begin{array}{r}42 \\
902 \\
0\end{array}$ & $\begin{array}{c}39 \\
808 \\
0.4\end{array}$ & $\begin{array}{c}38 \\
514 \\
1 \cdot 1\end{array}$ \\
\hline $\begin{array}{l}\text { Emergency coronary artery bypass } \\
\text { grafting }(\%) \\
\text { Myocardial infarction (\%) } \\
\text { Success }(\%)\end{array}$ & $\begin{array}{l}3 \cdot 3 \\
3 \cdot 0 \\
86\end{array}$ & $\begin{array}{l}1 \cdot 7 \\
2 \cdot 8 \\
88\end{array}$ & $\begin{array}{r}5 \cdot 3 \\
3 \cdot 8 \\
79\end{array}$ & $\begin{array}{l}1 \cdot 8 \\
0 \cdot 8 \\
91\end{array}$ & $\begin{array}{c}1 \cdot 4 \\
0 \cdot 4 \\
58\end{array}$ & $\begin{array}{l}1 \cdot 1 \\
1 \cdot 7 \\
86\end{array}$ \\
\hline
\end{tabular}

coronary artery bypass rate rose from $1 \cdot 7 \%$ to $2.6 \%$ between 1989 and 1990 .

\section{CLINICAL INDICATIONS FOR PERCUTANEOUS TRANSLUMINAL CORONARY ANGIOPLASTY \\ (TABLES 6 AND 7)}

The results were similar to those of 1989 . The definitions of unstable angina, post-thrombolysis, and acute myocardial infarction are the same as those used in the 1989 report.

\section{OTHER CORONARY INTERVENTIONAL} PROCEDURES (TABLE 7)

A small number of non-coronary angioplasty procedures were performed. Only information on the number of procedures was requested as this was the first year that these procedures had been surveyed.

RELATION BETWEEN CARDIAC CATHETERISATIONS AND PERCUTANEOUS TRANSLUMINAL CORONARY ANGIOPLASTIES (TABLE 8)

When all cardiac catheterisations for coronary artery and valvar heart disease in adults were included $13 \%$ (range $2-32 \%$ ) of procedures later led to percutaneous transluminal coronary angioplasty.

\section{SURGICAL COVER FOR PERCUTANEOUS} TRANSLUMINAL CORONARY ANGIOPLASTY

As in the 1989 survey interest and debate over surgical cover ${ }^{34}$ prompted a separate analysis of the results of the six cardiac units without on site cardiac surgical facilities (table 9). The requirement for emergency coronary artery bypass graft surgery was lower in the centres without on site surgery. This, however, was not

Table 7 Percutaneous transluminal coronary angioplasty in the United Kingdom in 1990: other procedures

\begin{tabular}{lll}
\hline Procedure & Centres & Numbers \\
\hline Rotacs & 6 & 35 \\
Stents & 2 & 13 \\
Atherectomy & 5 & 15 \\
Laser balloon & 1 & 7 \\
Excimer laser & 1 & 65 \\
\hline
\end{tabular}

Table 8 Relation between catheterisations and percutaneous transluminal coronary angioplasties (data from 46 cardiac units)

\begin{tabular}{lc}
\hline & Range \\
\hline $\begin{array}{l}\text { Total catheterisations (58197) } \\
\begin{array}{l}\text { Total percutaneous transluminal coronary } \\
\text { angioplasties (7445) }\end{array}\end{array}$ & $274-3300$ \\
$\begin{array}{l}\text { Going from percutaneous transluminal coronary } \\
\text { angioplasty to catheterisation }(13 \%)\end{array}$ & $10-428$ \\
\hline
\end{tabular}

at the expense of significant increases in mortality or myocardial infarction.

\section{Balloon dilatation of valves in adults (table 10)}

The frequency of balloon dilatation of aortic valves continued to fall whereas that for balloon dilatation of the mitral valve nearly doubled, from 112 in 1989 to 213 in 1990.

\section{Paediatric interventional procedures (table 11)}

The total number of procedures increased by $26 \%$ since 1989 . The range of procedures widened to include dilatation of subaortic stenosis and closure of ventricular septal defects. The paediatric interventional procedures had a low mortality and morbidity with the exception of balloon dilatation of the aortic valve.

\section{Comments on the 1990 survey of} procedures

Many cardiac units still had difficulty in providing complete data; there was no improvement since the 1989 audit.

The number of percutaneous transluminal coronary angioplasties per million population in the United Kingdom during 1990 remains considerably lower than that of the United States and many other countries of Western Europe. The mortality for single vessel dilatation has increased each year from 1988 to 1990 . The requirement for emergency

Table 9 Percutaneous transluminal coronary angioplasty in the United Kingdom in 1990: comparison between cardiac units with on site and off site surgical facilities

\begin{tabular}{lcl}
\hline & On site & Off site \\
\hline Cardiac units & 45 & 6 \\
Numbers & 7878 & 581 \\
Mortality & $56 / 7259(0 \cdot 77 \%)$ & $0 / 581$ \\
Emergency coronary & & \\
$\quad$ artery bypass & $161 / 7259(2 \cdot 2 \%)$ & $6 / 559(1 \cdot 1 \%)$ \\
grafting & $115 / 6139(1.9 \%)$ & $13 / 559(2 \cdot 3 \%)$ \\
\hline
\end{tabular}

Table 10 Balloon dilatation of valves in adults in the United Kingdom in 1990

\begin{tabular}{llrll}
\hline & $\begin{array}{l}\text { Cardiac } \\
\text { units }\end{array}$ & Numbers & Death & Complication \\
\hline Pulmonary & 10 & 16 & 0 & 0 \\
Aortic & 16 & 60 & 7 & 3 \\
Mitral & 20 & 213 & 2 & 5 \\
Coarction of & 2 & 6 & 0 & 1 \\
$\quad$ aorta & 2 & 14 & 0 & 0 \\
Miscellaneous & 9 & &
\end{tabular}


Table 11 Paediatric interventional procedures in the United Kingdom in 1990

\begin{tabular}{lllll}
\hline & $\begin{array}{l}\text { Cardiac } \\
\text { units }\end{array}$ & Number & Death & Complications \\
\hline Procedure & 21 & 258 & 3 & 0 \\
Pulmonary valve dilatation & 14 & 96 & 9 & 2 \\
Aortic valve dilatation & 2 & 2 & 0 & 0 \\
Mittal valve dilatation & 12 & 93 & 2 & 2 \\
Coarction of aorta & 12 & 159 & 0 & 4 \\
Closure of Patent ductus arteriosus & 8 & 33 & 0 & 0 \\
Pulmonary artery or branch stenosis dilatation & 8 & 23 & 0 & 0 \\
Mustard/Senning/caval dilatation & 3 & 7 & 0 & 0 \\
Shunt dilatation & 6 & 40 & 0 & 0 \\
Fallot's tetralogy & 9 & 24 & 0 & 0 \\
Embolisation & 2 & 6 & 0 & 0 \\
Subaortic stenosis & 5 & 7 & 0 & 0 \\
Retrieval & 6 & 11 & 1 & 0 \\
Blade septostomy & 1 & 3 & 0 & 0 \\
Closure of ventricular septal defect & 2 & 5 & 0 & 0 \\
Miscellaneous & & & & \\
\hline
\end{tabular}

coronary artery bypass grafting and the myocardial infarction rate remained much the same over these years. This increased mortality risk may be the result of more complicated cases, being attempted-such as less favourable lesions in one artery in patients with multivessel disease-rather than low risk lesions in patients with single vessel disease.

Thirteen percent of diagnostic angiograms later led to a coronary angioplasty procedure. This figure suggests that for the number of angioplasty procedures to rise to levels comparable to other countries in Western Europe-that is to $350-400$ per million-it will be necessary to increase the number of diagnostic angiograms as well as the funding for coronary angioplasty.

Paediatric interventional procedures increased in number and range and maintained their low mortality and morbidity.

The British Cardiovascular Intervention Society is grateful to the staff who compiled the data requested from each cardiac unit. The adult cardiology units that took part in the 1990 survey are the same as those listed in the 1989 survey $^{2}$ with the exception that the National Heart and the Brompton Hospitals have combined (as the Royal Brompton National Heart and Lun Hospital) and the Victoria Infirmary Glasgow did not provide any information. The paediatric Cardiology units are shown below.

Paediatric cardiac units surveyed in 1990

Belfast Royal Victoria Hospital, Birmingham Children's Hospital, Bristol Royal Children's Hospital, Edinburgh Royal Hospital for Sick Children, Glasgow Royal Children's Hospital, Great Ormond Street, Guy's Hospital, Hammersmith Hospital, Great Ormond Street, Guy's Hospital, Hammersmith Hospital, Harefield Hospital, Humana Wellington Hospital, Leeds Killingbeck Hospital, Leicester Groby Road Hospital, Liver-
pool Royal Children's Hospital, Manchester Royal Children's pool Royal Children's Hospital, Manchester Royal Children's Royal Brompton National Heart and Lung Hospital, Royal Free Hospital, Sheffield Northern General Hospital, Southampton General Hospital, St Thomas's Hospital.

1 Hubner PJB. Cardiac interventional procedures in the United Kingdom during 1988. Br Heart J 1990;64:36-7.

2 Hubner PJB on behalf of the British Cardiovascular Intervention Society. Cardiac interventional procedures in the United Kingdom in 1989. Br Heart $J$ 1991;66: 469-71.

3 Parker DJ. Does angioplasty need on site cover? A surgeon's view. Br Heart J 1990;64:1-2.

4 Shaw TRD. Does angioplasty need on site surgical cover? A physician's view. Br Heart J 1990;64:3-4. 